\title{
ASAS LEGALITAS SEBAGAI PONDASI HUKUM PIDANA PERSFEKTIF FILSAFAT HUKUM
}

\author{
CITRANU \\ IAHN Tampung Penyang \\ citranuhbdullah@gmail.com
}

\begin{abstract}
ABSTRAK
Hukum pidana merupakan seperangkat peraturan yang dibuat oleh negara yang berisikan perintah, dan larangan apabila dilanggar akan dikenakan sanksi pidana. Hukum pidana erat kaitannya dengan asas legalitas, karena asas legalitas merupakan dasar untuk penegakan hukum pidana. Tujuan dari hukum pidana adalah untuk mencari keadilan. Hukum pidana dalam hal mencapai suatu keadilan dengan cara penerapan asas legalitas sebagai pondasinya dapat dikaji lebih mendalam dan menyeluruh melalui filsafat hukum meliputi Ontologi hukum, Aksiologi hukum dan Epistimologi hukum, sehingga didapat hakikat dan makna terdalam dari asas legalitas adalah untuk mencapai damai sejahtera. Penyimpangan terhadap asas legalitas pun dapat dilakukan asalkan dengan tujuan mencari kebenaran dan keadilan guna terciptanya damai sejahtera, karena hukum sejatinya dinamis sebagaimana adigium hukum untuk manusia bukan manusia untuk hukum.
\end{abstract}

Kata Kunci : Asas Legalitas, Hukum Pidana, Filsafat Hukum 


\section{LATAR BELAKANG}

Hukum pidana di Indonesia erat kaitannya dengan asas legalitas, karena asas legalitas merupakan pondasi hukum pidana. Sebagai pondasi hukum pidana, asas legalitas memiliki peran penting didalam mewujudkan cita-cita dari pada hukum pidana. Asas legalitas memiliki hubungan dengan kepastian hukum, didalam penerapan hukum pidana, asas legalitas memiliki peran penting sebagai batasan terhadap penegakan hukum pidana, karena makna yang terkandung didalam asas legalitas yang menekankan suatu perbuatan dapat dipidana apabila ada aturan hukum yang mengaturnya terlebih dahulu yakni aturan hukum pidana dalam bentuk undang-undang pidana.

Undang-undang pidana tidak selalu dapat dijadikan sebagai pemecahan suatu masalah, apalagi apabila berbicara terkait kebenaran, keadilan, kemanfaatan dan kepastian hukum, guna terciptanya kedamaian sebagaimana hakikat dari hukum pidana, sehingga kembali lagi kepada filsafat hukum yang mana kajiannya lebih luas dan lebih menyeluruh. Filsafat hukum merupakan cabang ilmu yang mengkaji hukum sampai ke akarnya, filsafat hukum memandang hukum pidana sebagai objek kajiannya untuk mencari kebenaran dan keadilan. Menurut asas legalitas segala macam perbuatan pidana harus diatur didalam undang-undang, perbuatan pidana 
dirumuskan didalam ketentuan pasal undang-undang pidana. Muncul sebuah pertanyaan apakah bisa asas legalitas dikesampingkan dengan tujuan mencari kebenaran dan keadilan serta bagaimana kajian terhadap penyimpangan asas legalitas tersebut dari sudut pandang filsafat hukum.

Penyimpangan terhadap asas legalitas didalam hukum pidana merupakan sebuah pertentangan besar dengan aliran positivisme hukum, karena menurut pandangan positivisme yakni hukum harus tertulis dalam bentuk undang-undang, tidak mungkin orang dihukum tidak berdasarkan undang-undang pidana, sedangkan kita ketahui sebagaimana sumber hukum itu tidak hanya peraturan tertulis saja melainkan juga peraturan yang tidak tertulis meliputi hukum kebiasaan atau hukum adat yang hidup dan tumbuh serta berkembang didalam masyarakat, orang bisa saja dihukum karena melanggar norma, ataupun kaidah yang ada didalam masyarakat dikarenakan perbuatan seseorang tersebut telah mengganggu kestabilan atau keseimbangan didalam masyarakat sehingga terjadi keresahan didalam masyarakat maka perbuatan tersebut harus dilakukan penghukuman terhadap pelakunya, walaupun sejatinya perbuatan tersebut tidak termasuk didalam rumusan ketentuan undang-undang pidana.

Penyimpangan terhadap asas legalitas ini lebih kepada tujuan dari pada hukum pidana itu sendiri, seperti terciptanya masyarakat yang adil, tertib, damai sejahtera. hukum harus memberikan rasa keadilan dan 
kemanfaatan kepada masyarakat tidak hanya mementingkan kepastian hukum saja. Kajian filsafat hukum memiliki cakupan yang sangat luas terhadap asas legalitas sehingga dapat melihat dari berbagai macam sudut pandang, memaknai asas legalitas jauh lebih dalam sampai medapatkan suatu hakikat yang memiliki peran penting untuk pondasi dasar didalam pelaksanaan dan penerapan hukum pidana dimasa sekarang dan dimasa yang akan datang.

Berdasarkan hal tersebut diatas penulis tertarik mengkaji asas legalitas dari sudut pandang filsafat hukum agar bisa mengetahui dan memahami makna terdalam ataupun hakikat dari asas legalitas pada hukum pidana, maka dari pada itu penulis beri judul tulisan ini Asas Legalitas Sebagai Pondasi Hukum Pidana Persfektif Filsafat Hukum.

\section{PEMBAHASAN}

\section{Asas Legalitas Sebagai Pondasi Hukum Pidana Persfektif Filsafat Hukum}

Asas legalitas menurut waktu sebagaimana Pasal 1 ayat 1 KUHP mengandung makna : (Moeljatno. 1993: 25)

1) Tiada suatu perbuatan dapat dipidana kecuali ada undang-undang yang mengaturnya terlebih dahulu;

2) Larangan melakukan penafsiran analogi atau kiyas dalam hukum pidana

3) Ketentuan hukum pidana tidak berlaku surut

Asas legalitas menurut ruang / tempat sebagaimana Pasal 2 s.d Pasal 9 KUHP mengandung makna: (P.A.F. Lamintang. 1997 : 89) 
1) Asas Teritorial; artinya menitikberatkan pada terjadinya tindak pidana di wilayah negara.

2) Asas Personal (Nasional Aktif) artinya undang-undang pidana berlaku bagi semua tindak pidana yang dilakukan oleh warga negara dimanapun berada, baik didalam negara maupun diluar wilayah negara.

3) Asas Perlindungan (Nasional Pasif) artinya perlindungan terhadap kepentingan nasional, yang memungkinkan undang-undang pidana berlaku bagi siapa saja yang melakukan tindak pidana yang berhubungan dengan keamanan dan integritas negara.

4) Asas Universal artinya undang-undang pidana suatu negara dapat diberlakukan terhadap kejahatan internasional. Setiap negara mempunyai kewajiban memelihara keamanan dan ketertiban dunia. (P.A.F. Lamintang. 1997: 90)

Filsafat hukum merupakan perenungan terhadap aspek filosofis dari eksistensi hukum dan penerapan hukum guna tercapai hakikat hukum yang sesungguhnya.

Kajian filsafat hukum terhadap eksistensi hukum meliputi: (I Dewa Gede Atmagja. 2013: 11)

1) Ontologi Hukum

Ontologi hukum merupakan kajian terhadap hakekat dari hukum, menerangkan dan mencerahkan bahwa hukum sejatinya digunakan untuk membimbing manusa ke arah yang lebih baik;

Makna yang terkandung didalam Asas Legalitas berdasarkan Ontologi Hukum adalah sebagai berikut:

- Tiada suatu perbuatan dapat dipidana kecuali ada undang-undang yang mengaturnya terlebih dahulu sehingga pertama menurut aliran hukum 
alam atau aliran hukum kodrat memandang hakikat undang-undang adalah suatu kebenaran dan keadilan serta moral yang bersifat kodrat dan universal sehingga segala peraturan hakekatnya bersifat tertulis dalam bentuk undang-undang layaknya kitab suci berisikan wahyu Tuhan yang dituangkan dalam bentuk tertulis. Segala perbuatan yang dapat dipidana termuat didalam undang-undang sehingga orang dihukum karena melanggar undang-undang dan keadilan hanya dapat dicapai melalui undang-undang atau keadilan menurut undang-undang, hal ini juga menjadi fokus dari kajian ontologi hukum yang mencari hakikat dari asas legalitas bahwa hukum itu tertulis, tertulis sebenarnya lebih kepada kemudahan untuk mengingat, memastikan bahwa hukum itu tidak berubah dan senantiasa bersifat tetap kedua menurut aliran positivisme secara jelas minitikberatkan norma positif didalam undang-undang, sehingga tidak ada hukum diluar undang-undang, dalam hal ini hanya dengan undang-undang tindak pidana dapat dinyatakan serta kepastian hukum hanya akan dicapai melalui undang-undang, persfektif positivisme sangat kaku dan berpedoman dengan apa yang tertulis didalam undang-undang, keadilan hanya dapat dicapai melalui undangundang, sehingga muncul istilah keadilan berdasarkan undang-undang yang artinya aturan hukum apa yang tertulis didalam undang-undang dan dilaksanakan atau diterapkan pada kasus konkrit maka output dari 
putusan hakim yang menerapkan sesuai dengan isi rumusan pasal maka itulah keadilan, ketiga menurut utilitarianisme hukum juga menitikberatkan kepada undang-undang yang berisikan norma positif didalam suatu perbuatan yang dilarang didalam undang-undang pidana sehingga undang-undang pidana tersebut melahirkan suatu kemanfaatan hukum, ketentuan hukum atau norma hukum yang termuat didalam undang-undang dibuat untuk memberikan kemanfaatan kepada masyarakat, kemanfaatan untuk masyarakat dalam hal aturan hukum tersebut diterapkan secara baik dan benar, keempat menurut aliran sejarah hukum yakni undang-undang harus berdasarkan jiwa suatu bangsa atau sejarah suatu bangsa, karena hukum harus sesuai dengan perkembangan masyarakat atau bangsa, dalam hal ini perbuatan yang dapat dikatakan sebagai suatu tindak pidana harus sesuai dengan perkembangan masyarakat dan berdasarkan sudut pandang masyarakat, artinya suatu rumusan undang-undang dalam pembentukannya harus mencerminkan sejarah suatu bangsa, walaupun dari sudut pandang aliran sejarah hukum terkait lahirnya hukum tidak dibuat melainkan hidup dan tumbuh berkembang berdasarkan sejarah suatu bangsa, akan tetapi pada penerapan asas legalitas selaras dengan pengkategorian suatu perbuatan pidana, sehingga pelaku dapat dihukum karena melanggar undangundang yang mencerminkan perkembangan sejarah hukum didalam 
masyarakat. Hukum yang dibuat secara tertulis harus menyesuaikan dan mengambil dari nilai-nilai sejarah hukum suatu bangsa, nilai-nilai keadilan yang hidup dan berkembang didalam masyarakat harus diakomodir didalam suatu ketentuan hukum tertulis yakni undangundang.

- Larangan melakukan penafsiran analogi atau kiyas dalam hukum pidana, pertama menurut aliran hukum alam memandang larangan penafsiran analogi yakni ketentuan undang-undang harus jelas tidak boleh adanya perluasan makna kata secara kiyas dari suatu rumusan undang-undang, karena hakikat undang-undang bertujuan untuk menyatakan kebenaran, apabila penafsiran analogi diterapkan terhadap undang-undang maka dapat menimbulkan ketidakadilan dan mengurangi dari makna kebenaran itu sendiri karena patokannya adalah undang-undang tertulis. Apa yang termuat dan tertuang didalam rumusan undang-undang itulah hukumnya tidak boleh dibelokan untuk menyesuaikan apa yang menjadi argumentasi. Kedua menurut aliran positivisme, panafsiran hanya bisa dilakukan berdasarkan penafsiran otentik yang mana penafsiran tersebut telah jelas termuat didalam undang-undang yakni ketentuan penjelasan dari undang-undang itu sendiri, apabila ada ketidakjelasan terhadap undang-undang maka dibatasi terhadap jenis penafsiran tertentu yang tetap menitikberatkan kepada kepastian hukum. Aliran positivisme secara 
tegas melarang dilakukannya analogi atau kiyas terhadap undangundang karena bisa menimbulkan ketidakpastian hukum. Ketiga menurut utilitarianisme hukum bahwa penafsiran analogi terhadap ketentuan undang-undang bisa saja dilakukan apabila mendatangkan kemanfaatan hukum akan tetapi apabila tidak memberikan kemanfaatan maka penafsiran analogi tersebut tidak dilakukan, karena didalam penegakan hukum pidana harus memberikan kemanfaatan hukum kepada negara, masyarakat, korban dan kepada pelaku tindak pidana itu sendiri tanpa keluar dari konteks kepastian hukum. Keempat menurut aliran sejarah hukum bahwa undang-undang ditafsirkan berdasarkan pandangan masyarakat atau perkembangan sejarah suatu bangsa, sehingga penafsiran analogi terhadap ketentuan pidana bisa saja diterapkan asalkan tidak bertentangan dengan sudut pandang sejarah bangsa atau perkembangan masyarakat, sebaliknya apabila penafsiran analogis tersebut bertentangan dengan sejarah suatu bangsa atau perkembangan sejarah hukum dimasyarakat maka penafsiran analogis tidak boleh diberlakukan.

- Ketentuan hukum pidana tidak berlaku surut yakni ketentuan undangundang pidana jauh harus sudah ada terlebih dahulu sebelum perbuatan pidana itu terjadi, sehingga perbuatan pidana tersebut bisa dikategorikan sebagai tindak pidana dan orang yang melakukan perbuatan pidana 
tersebut bisa dipidana karena melanggar undang-undang pidana. Pertama menurut aliran hukum alam yakni penerapan asas non retroaktif selaras dengan tujuan hukum yakni kebenaran dan keadilan, karena tidak mungkin orang dipidana tanpa adanya aturan yang terlebih dahulu ada, begitu juga tidak adil apabila undang-undang yang baru dibuat bisa menghukum perbuatan diwaktu lampau. Dua makna yang terkandung didalam asas legalitas yakni tiada perbuatan dapat dipidana kecuali ada ketentuan undang-undang yang mengaturnya terlebih dahulu memiliki keselarasan dengan hukum pidana tidak berlaku surut. Tujuan dari asas non retroaktif selain dari pada kepastian hukum adalah mencari kebenaran dan keadilan berdasarkan undang-undang. Kedua menurut aliran positivisme bahwa asas non retroaktif jelas bertentangan dengan kepastian hukum, undang-undang mengandung norma positif, sehingga seringkali undang-undang dikatakan sebagai hukum positif atau ketentuan hukum yang berlaku saat ini, maka ketentuan hukum yang berlaku saat ini tidak bisa diterapkan terhadap perbuatan dimasa lampau yang sebelumnya hukum positif tersebut belum dibentuk. Ketiga menurut utilitarianisme hukum, bahwa asas non retroaktif tidak memberikan manfaat apabila dalam hal penerapannya bertentangan dengan undang-undang yang mencerminkan kepastian hukum, karena hakekat hukum menurut ontologi hukum dalam hal ini utilitarianisme 
adalah norma positif yang dituangkan ke dalam peraturan perundangundangan. Keempat menurut aliran sejarah hukum bahwa sejarah hukum suatu bangsa selalu berkembang sesuai dengan perkembangan masyarakat sehingga sejarah hukum selalu berjalan dinamis sehingga hukum pun akan selalu berkembang khususnya hukum pidana, yakni yang dulunya suatu perbuatan bukan merupakan tindak pidana seiring perkembangan masyarakat maka perbuatan tersebut berubah menjadi tindak pidana, begitu sebaliknya perbuatan pidana karena perkembangan masyarakat perbuatan tersebut berubah menjadi bukan tindak pidana lagi. Dalam hal ini asas non retroktif tidak bisa diterapkan menurut aliran sejarah karena hukum pidana harus dinamis mengikuti perkembangan masyarakat tidak kaku sehingga bisa tercapainya keadilan menurut jiwa suatu bangsa atau masyarakat, hukum pidana tidak bisa diberlakukan mundur ke belakang.

- Asas Teritorial; artinya menitikberatkan pada terjadinya tindak pidana di wilayah negara. Pertama, menurut aliran hukum alam terkait asas teritorial merupakan suatu batasan terhadap berlakunya undang-undang pidana yang berpegang pada kepentingan hukum pidana yang dimiliki setiap negara, karena pada era modern hukum memiliki batasan ruang berlakunya tergantung kepada batasan wilayah kekuasaan suatu negara yang berdaulat, sehingga antara hukum negara yang satu dengan negara 
yang lain memiliki batasan kekuatan mengikat terhadap perbuatan yang dilakukan pada suatu wilayah negara. walaupun sejatinya hukum pidana adalah bersifat universal, tidak terkotak-kotak akan tetapi karena kedaulatan negara dan setiap negara memiliki hukum pidananya masingmasing maka wajib untuk menghormati teritorial berlakunya hukum pidana tersebut dengan tidak mengesampingkan atau melanggar hukum internasional. Kedua menurut aliran positivisme terkait asas teritorial adalah syarat mutlak untuk menjaga kepentingan hukum pidana suatu negara, kepentingan hukum pidana disini dalam arti melindungi negara dari perbuatan pidana yang terjadi di wilayah hukumnya sehingga perbuatan pidana yang dilakukan didalam teritorialnya tersebut dapat diadili dan dihukum berdasarkan hukum pidana yang berlaku dengan tetap memperhatikan hukum internasional. Ketiga menurut utilitarianisme hukum terhadap asas teritorial yakni memiliki manfaat melindungi kepentingan negara didalam wilayah hukum negaranya sendiri sebagai bentuk jaminan kepastian hukum terhadap siapa saja yang melakukan perbuatan pidana diwilayah hukum negara, Keempat menurut aliran sejarah hukum terkait asas teritorial dari sisi penerapannya tergantung kepada sejarah terbentuknya hukum pidana yang berasal dari perkembangan masyarakat yang dituangkan ke dalam bentuk undang-undang yang berisikan teritorial berlakunya hukum 
pidana sebagai batasan terhadap hukum pidana sesuai dengan wilayah negara, artinya aliran sejarah hukum mengakui adanya asas teritorial hukum pidana asalkan berkesesuaian berdasarkan sejarah hukumnya.

- Asas Personal (Nasional Aktif) artinya undang-undang pidana berlaku bagi semua tindak pidana yang dilakukan oleh warga negara dimanapun berada, baik didalam negara maupun diluar wilayah negara. Pertama menurut aliran hukum alam terhadap asas personal / nasional aktif yakni sepanjang suatu undang-undang hukum pidana tersebut dianggap sebagai suatu kebenaran maka aturan pidana tersebut mutlak diterapkan, walaupun dalam penerapan asas nasional aktif ini sering bertentangan dengan hukum internasional yang mewajibkan menghargai dan mematuhi hukum dari negara lain sehingga penerapan terhadap asas personal / nasional aktif wajib memperhatikan hukum internasional dengan cara melakukan perjanjian antar negara untuk menerapkannya agar dalam penegakan hukum pidana terdapat pengecualian terhadap asas teritorial hukum suatu negara dan juga agar pemberlakuan hukum pidana tidak melanggar hukum pidana dari negara lain. Kedua menurut aliran positivisme terhadap asas personal / nasional aktif yakni apa yang tertulis pada undang-undang maka wajib dilaksanakan, sehingga pelaku tindak pidana yang berwarganegara Indonesia apabila ia melakukan tindak pidana di negara lain maka akan dikenakan atau diterapkan 
hukum pidana indonesia akan tetapi pada prakteknya asas personal / nasional aktif sangat sulit dilaksanakan karena berbenturan dengan hukun pidana negara lain sehingga membutuhkan perjanjian antar negara agar asas ini dapat diterapkan, Ketiga menurut utilitarianisme hukum terhadap asas personal / nasional aktif yakni memiliki kemanfaatan untuk melindungi warga negara agar jangan sampai dihukum oleh negara lain, aliran utilitarianisme juga berpandangan bahwa asas personal / nasional aktif sebagai cerminan kedaulatan hukum suatu negara yang menjaga dan melindungi segenap tumpah darah warga negaranya. Keempat menurut aliran sejarah hukum terhadap asas personal / nasional aktif yakni hukum pidana wajib melindungi warga negaranya hal ini selaras dengan jiwa suatu bangsa, apabila hukum pidana tidak melindungi warga negaranya maka hukum pidana tersebut bukan merupakan hukum pidana yang mencerminkan jiwa suatu bangsa yang berdaulat.

- Asas Perlindungan (Nasional Pasif) artinya perlindungan terhadap kepentingan nasional, yang memungkinkan undang-undang pidana berlaku bagi siapa saja yang melakukan tindak pidana yang berhubungan dengan keamanan dan integritas negara. Pertama menurut aliran hukum alam terhadap asas perlindungan / nasional pasif yakni undang-undang bertujuan untuk melindungi maka harus diterapkan oleh negara, asas perlindungan dijadikan sebagai manifestasi kebenaran didalam 
menerapkan hukum pidana, dalam hal ini perlindungan terhadap kepentingan negara, melindungi terhadap ancaman kedaulatan negara sehingga hukum pidana dijadikan sebagai alat pelindung negara, Kedua menurut aliran positivisme yakni asas perlindungan / nasional pasif pada dasarnya adalah undang-undang yang apabila dilanggar maka akan dikenakan sanksi pidana terhadap pelakunya, sehingga apabila perbuatan pidana berhubungan dengan keamanan negara tidak ada toleransi walaupun didalam penerapan asas perlindungan / nasional pasif bertentangan dengan hukum internasional, Ketiga menurut utilitarianisme hukum bahwa asas perlindungan memberikan manfaat kepada negara maka wajib diterapkan kepada siapa saja yang melakukan perbuatan yang menggangu keamanan negara, Keempat menurut aliran sejarah hukum bahwa asas perlindungan / nasional pasif selaras dengan sejarah bangsa yang berhubungan dengan kepentingan negara, asas perlindungan memiliki hubungan erat dengan keberlangsungan mempertahankan negara.

- Asas Universal artinya undang-undang pidana suatu negara dapat diberlakukan terhadap kejahatan internasional. Setiap negara mempunyai kewajiban memelihara keamanan dan ketertiban dunia. Pertama menurut aliran hukum alam bahwa asas universal terkait hukum pidana adalah setiap orang dihukum berdasarkan undang-undang dan perbuatan yang 
dapat dihukum merupakan perbuatan yang negatif yang dapat merugikan orang lain serta tentunya perbuatan tersebut diatur oleh undang-undang, dalam hal ini suatu perbuatan pidana yang dinyatakan oleh masyarakat internasional atau negara-negara didunia sebagai suatu perbuatan negatif yang dapat merugikan dan memiliki efek yang luas sehingga perbuatan tersebut diberi label sebagai kejahatan internasional salah satu contohnya kejahatan kemanusiaan atau terorisme sehingga setiap negara dapat memberlakukan hukum pidananya terhadap tindak pidana terorisme, Kedua menurut aliran positivisme bahwa asas universal terhadap perbuatan yang melanggar norma hukum pidana, dan terkait perbuatan pidana tersebut oleh masyarakat internasional dinyatakan sebagai suatu pernyataan sikap yang pantas untuk dikenakan sanksi pidana oleh undang-undang pidana dari masing-masing negara, Ketiga menurut utilitarianisme hukum bahwa asas universal dapat diterapkan dan diakui asalkan memberikan manfaat kepada negara, yakni salah satunya penegakan hukum pidana terkait kejahatan internasional guna terciptanya perdamaian dunia, Keempat menurut aliran sejarah hukum bahwa asas universal harus selaras dengan jiwa suatu bangsa atau negara, apabila asas universal hukum pidana tersebut bertentangan dengan jiwa suatu bangsa maka asas universal haruslah ditolak dan tidak dapat diberlakukan. 
2) Aksiologi Hukum

Aksiologi Hukum mencakup kajian dari nilai hukum. (I Dewa Gede Atmagja. 2013: 16)

Makna yang terkandung didalam Asas Legalitas berdasarkan Aksiologi Hukum adalah sebagai berikut:

- Tiada suatu perbuatan dapat dipidana kecuali ada undang-undang yang mengaturnya terlebih dahulu; Pertama menurut aliran hukum alam bahwa tujuan hukum adalah keadilan maka hukum pidana harus memberikan keadilan didalam penerapannya tidak hanya mementingkan kepastian hukum saja, hukum pidana digunakan untuk mendatangkan kebaikan serta berfungsi sebagai ketertiban dan kedamaian didalam masyarakat, dalam hal perbuatan pidana yang diatur didalam undangundang pidana harus menjadikan keadilan sebagai prioritas utama, Kedua menurut aliran positivisme bahwa tujuan hukum adalah untuk mencapai kepastian hukum yang artinya segala perbuatan hanya dapat dikatakan sebagai perbuatan pidana apabila diatur didalam undangundang pidana sehingga apabila terjadi perbuatan pidana maka pelakunya dapat dihukum berdasarkan undang-undang pidana, Ketiga menurut utilitarianisme hukum bahwa hukum bertujuan untuk memberikan kemanfaatan artinya hukum pidana harus memberikan 
kemanfaatan kepada masyarakat, didalam penerapannya undang-undang pidana tidak hanya untuk menghukum orang saja melainkan undangundang pidana bisa merubah dan menyadarkan orang agar jangan sampai melakukan tindak pidana, sehingga rumusan ketentuan yang berisikan perbuatan-perbuatan yang dilarang didalam undang-undang pidana wajib memberikan kemanfaatan, Keempat menurut aliran sejarah hukum bahwa hukum harus memberikan kemanfaatan dan keadilan artinya perbuatan pidana yang tercantum didalam undang-undang pidana harus memberikan kemanfaatan dan rasa keadilan kepada masyarakat sehingga didalam penerapan undang-undang pidana tidak bertentangan dengan jiwa suatu bangsa sebagaimana ajaran aliran sejarah hukum yang menyatakan hukum yang baik adalah hukum yang berdasarkan jiwa suatu bangsa begitu juga dengan pembentukan ketentuan hukum pidana harus mengakomodir sejarah hukum suatu bangsa.

- Larangan melakukan penafsiran analogi atau kiyas dalam hukum pidana, Pertama menurut aliran hukum alam bahwa undang-undang pidana tidak boleh dilakukan penafsiran analogi atau kiyas karena bisa mengurangi makna keadilan, Kedua menurut aliran positivisme bahwa tidak diperbolehkan analogi atau kiyas terhadap undang-undang pidana karena setiap undang-undang memiliki penjelasan otentiknya masing- 
masing apabila ada kata atau bahasa yang memerlukan penjelasan lebih lanjut selain rumusan cukup jelas sehingga tetap pada kerangka kepastian hukum, Ketiga menurut utilitarianisme hukum bahwa analogi atau kiyas tidak bisa diterapkan didalam undang-undang pidana karena sudah secara tegas dilarang dan dinyatakan bertentangan dengan kepastian hukum, nilai kemanfaatan didapat tetap didalam konteks kepastian hukum, Keempat menurut aliran sejarah hukum bahwa analogi atau kiyas dilarang karena bisa bertentangan dengan keadaan masyarakat dan bisa menimbulkan ketidakadilan apabila diterapkan didalam undangundang hukum pidana.

- Ketentuan hukum pidana tidak berlaku surut, Pertama menurut aliran hukum alam bahwa penerapan asas retro aktif didalam hukum pidana dapat menimbulkan ketidakadilan, Kedua menurut aliran positivisme bahwa secara tegas asas retro aktif bertentangan dengan kepastian hukum sehingga didalam hukum pidana tidak boleh diterapkan, Ketiga menurut utilitarianisme hukum bahwa asas retro aktif tidak memberikan kemanfaatan apabila didalam penerapannya bertentangan dengan kepastian hukum, karena kemanfaatan hukum disini tetap pada konteks undang-undang yang menitikberatkan pada kepastian hukum, Keempat menurut aliran sejarah hukum bahwa penerapan asas retro aktif dapat mengakibatkan pertentangan dengan rasa keadilan yang ada pada 
masyarakat, karena aliran sejarah hukum lebih menitikberatkan kepada keadilan yang berdasarkan jiwa masyarakat atau jiwa suatu bangsa, tidak bisa undang-undang pidana yang baru dibuat menghukum perbuatan orang pada masa lampau sebelum undang-undang itu ada, hal itu bisa menciderai rasa keadilan.

- Asas Teritorial; artinya menitikberatkan pada terjadinya tindak pidana di wilayah negara.

- Asas Personal (Nasional Aktif) artinya undang-undang pidana berlaku bagi semua tindak pidana yang dilakukan oleh warga negara dimanapun berada, baik didalam negara maupun diluar wilayah negara.

- Asas Perlindungan (Nasional Pasif) artinya perlindungan terhadap kepentingan nasional, yang memungkinkan undang-undang pidana berlaku bagi siapa saja yang melakukan tindak pidana yang berhubungan dengan keamanan dan integritas negara.

- Asas Universal artinya undang-undang pidana suatu negara dapat diberlakukan terhadap kejahatan internasional. Setiap negara mempunyai kewajiban memelihara keamanan dan ketertiban dunia.

Menurut aksiologi hukum terhadap Asas Teritorial, Asas Personal (Nasional Aktif), Asas Perlindungan (Nasional Pasif), dan Asas Universal merupakan sarana untuk mencari keadilan, dimana hukum terlihat memiliki batasan karena terkotak-kotak oleh hukum masing-masing suatu 
negara ataupun doktrin dari pada ahli-ahli hukum yang dianut, padahal hukum sejatinya memiliki tujuan yang universal yakni mencapai suatu kebenaran dan keadilan, karena Asas Teritorial, Asas Personal (Nasional Aktif), Asas Perlindungan (Nasional Pasif), dan Asas Universal hanyalah cerminan pelaksanaan dari hukum itu sendiri.

\section{3) Epistimologi Hukum}

Epistimologi Hukum mengkaji tentang pengetahuan hukum / metodologi hukum. (I Dewa Gede Atmagja. 2013: 18)

Makna yang terkandung didalam Asas Legalitas berdasarkan Epistimologi Hukum adalah sebagai berikut:

- Tiada suatu perbuatan dapat dipidana kecuali ada undang-undang yang mengaturnya terlebih dahulu; Pertama menurut aliran hukum alam, hukum merupakan kodrat (hukum sebagai suatu metode) sehingga manusia wajib mematuhi hukum yakni hukum yang berasal dari Tuhan, begitu juga hukum yang berasal dari negara atau pemerintah yang berdaulat, masyarakatnya memiliki kewajiban mematuhi hukum Kedua menurut aliran positivisme adalah hukum yang berasal dari manusia, sebagai contoh bahwa hukum adalah perintah negara yang harus ditaati artinya undang-undang yang dibuat oleh negara merupakan perintah 
negara sehingga segala macam perbuatan atau tindak pidana harus dituangkan didalam undang-undang sehingga pelaku dapat dihukum karena melanggar perintah negara melalui undang-undang, Ketiga menurut utilitarianisme hukum sama halnya dengan positivisme hukum menitikberatkan kepada doktrinal deduktif yang mana undang-undang harus memberikan manfaat kepada masyarakat artinya undang-undang dijadikan sebagai metode untuk mendapatkan kemanfaatan kepada masyarakat dalam hal ini batasan terhadap orang yang dapat dihukum apabila melanggar isi undang-undang yang mana perbuatan tersebut telah tercantum didalam undang-undang pidana, Keempat menurut aliran sejarah hukum yakni pengetahuan hukum hanya dapat diperoleh melalui epistimologi empiris, yakni pengalaman dari sejarah berlakunya asas "Tiada suatu perbuatan dapat dipidana kecuali ada undang-undang yang mengaturnya terlebih dahulu" di dalam masyarakat, apakah melahirkan suatu kepastian hukum, kemanfaatan atau keadilan menurut pengetahuan hukum empiris.

- Larangan melakukan penafsiran analogi atau kiyas dalam hukum pidana menurut aliran hukum alam, aliran positivisme, utilitarianisme hukum, aliran sejarah hukum, penafsiran kiyas atau analogi bisa saja dilakukan baik secara metode ataupun pengetahuannya akan tetapi diluar dari pada konteks hukum pidana, karena apabila diterapkan pada konteks hukum 
pidana maka dapat mengaburkan makna unsur tindak pidana karena berhubungan dengan sesuatu yang kongkrit yang dalam hal ini adalah perbuatan pidana yang dilakukan seseorang dan bisa saja bertentangan dengan kepastian hukum, kemanfaatan dan keadilan. Penafsiran analogis menjadikan unsur pidana yang bersifat konkrit menjadi abstrak dan semakin luas maka penerapan rumusan pasalnya juga akan menjadi berbeda dan berubah-ubah tergantung dari konteks dari makna kiyasnya.

- Ketentuan hukum pidana tidak berlaku surut menurut aliran hukum alam, aliran positivisme, utilitarianisme hukum, aliran sejarah hukum, bisa diakukan untuk metode ilmiah dan pengetahuan akan tetapi tidak bisa dilakukan dalam kontek hukum pidana karena bertentangan dengan kepastian hukum dan bisa juga bertentangan dengan rasa keadilan pada masyarakat serta kemanfaatan hukum untuk masyarakat dalam kerangka undang-undang pidana. Pada kasus tertentu ada yang membolehkan asas berlaku surut diberlakukan, karena berhubungan dengan keadaan dimasa lampau untuk kepentingan hukum dimasa sekarang.

- Asas Teritorial, Asas Personal (Nasional Aktif), Asas Perlindungan (Nasional Pasif), Asas Universal menurut epistimologi hukum adalah suatu capaian tertinggi dari hukum itu sendiri yakni usaha melakukan kebenaran untuk mendatangkan damai sejahtera melalui metode penelitian hukum dan pengetahuan hukum. 


\section{Penyimpangan Terhadap Asas Legalitas Untuk Mencari Kebenaran dan}

\section{Keadilan}

1) Menghukum orang dengan menggunakan hukum kebiasaan atau hukum yang hidup dan berkembang didalam masyarakat karena hukum tertulis atau undang-undang tidak ada mengatur perbuatan tersebut sebagai suatu tindak pidana: menurut Ontologi hukum sudah selayaknya apabila hakikat dari pada hukum itu adalah untuk mendatangkan kedamaian sehingga orang yang melakukan kesalahan dan perbuatan yang tidak patut dimasyarakat dapat dihukum karena telah menciderai nilai kepatutan yang ada di masyarakat. Menurut Aksiologi hukum apabila menghukum orang yang melakukan perbuatan yang bertentangan dengan norma, kaidah dan nilai kepatutan yang ada pada masyarakat adalah suatu jalan untuk mencapai keadilan. Menurut Epistimologi hukum keadilan dapat dijadikan sebagai metode ilmiah dan pengetahuan untuk menegakkan hukum yang tidak tertulis guna terciptanya keadilan dan damai sejahtera.

2) Membebaskan orang dari hukuman karena menurut hukum kebiasaan atau hukum yang hidup dan berkembang didalam masyarakat perbuatan yang dilakukan tersebut bukan merupakan perbuatan tercela walaupun menurut undang-undang pidana perbuatan tersebut diatur didalam 
undang-undang pidana dan termasuk sebagai tindak pidana: Menurut Ontologi hukum suatu perbuatan apabila tidak merugikan masyarakat maka perbuatan tersebut bukanlah suatu perbuatan tercela sehingga pelaku tidak bisa dihukum, karena hakikatnya hukum dapat juga dijadikan sebagai pengampunan agar terciptanya kedamaian. Menurut Aksiologi hukum keadilan yang hidup dan berkembang didalam masyarakat merupakan dasar untuk terciptanya kedamaian sehingga sepatutnya apabila pelaku dibebaskan dari hukuman karena perbuatan yang dilakukan bukan merupakan perbuatan yang tercela dan dianggap tidak merugikan masyarakat. Menurut Epistimologi hukum keadilan sebagai metode pengetahuan agar kedamaian bisa terwujud.

3) Melakukan analogi terhadap suatu rumusan pasal pada kasus tertentu: Menurut Ontologi hukum, analogi bisa dilakukan untuk mengungkap suatu kebenaran, karena tujuan dari analogi bisa untuk memperjelas makna dari pada rumusan pasal yang kurang jelas, menurut Aksiologi hukum apabila analogi digunakan untuk mencari kebenaran bisa dilakukan dengan berdasar kepada keadilan, begitu juga menurut Epistimologi hukum yang menggunakan metode dan pengetahuan terkait analogi untuk mencari kebenaran guna mencapai keadilan.

4) Memberlakukan suatu aturan yang baru terhadap perbuatan yang telah lama dilakukan sebelum aturan tersebut ada: menurut Ontologi hukum, 
Aksiologi hukum, Epistimologi hukum, yakni retro aktif bisa digunakan guna mencari kebenaran dan keadilan guna mewujudkan damai sejahtera, tergantung dari pada konteks yang menjadi permasalahan sebagai contoh terhadap pelanggaran HAM dimasa lalu bisa diterapkan asas retro aktif.

5) Menolak penerapan asas universalitas hukum pidana: Menurut Ontologi hukum, Aksiologi hukum, Epistimologi hukum, yakni penolakan terhadap asas universalitas bisa dilakukan untuk mencari kebenaran dan keadilan guna mewujudkan damai sejahtera, karena aturan hukum juga memiliki batasan berlakunya, tidak semua aturan hukum bisa diberlakukan tergantung wilayah dan ruang lingkup aturan hukum itu berkaitan dengan teks dan konteks hukum.

\section{KESIMPULAN}

Pandangan filsafat hukum terhadap asas legalitas meliputi: Ontologi hukum memandang asas legalitas sebagai upaya untuk mencari keadilan yang hakiki untuk memperoleh kedamaian, hukum pidana digunakan untuk mendatangkan kebaikan serta berfungsi sebagai ketertiban dan kedamaian didalam masyarakat, Aksiologi hukum memandang asas legalitas dalam hal perbuatan pidana yang diatur didalam undang-undang pidana harus 
menjadikan keadilan sebagai prioritas utama, Epistimologi hukum memandang asas legalitas suatu capaian tertinggi dari hukum itu sendiri yakni kebenaran untuk mendatangkan damai sejahtera melalui metode penelitian hukum dan pengetahuan hukum. Menurut Ontologi hukum, Aksiologi hukum dan Epistimologi hukum, penyimpangan terhadap asas legalitas bisa saja dilakukan asalkan dengan tujuan mencari kebenaran dan keadilan guna tercapainya damai sejahtera. 


\section{Daftar Pustaka}

Atmagja I Dewa Gede. 2013. Filsafat Hukum Dimensi Tematis \& Historis. Malang:

Setara Press.

Darmodiharjo Darji dan Shidarta. 1999. Pokok-Pokok Filsafat Hukum apa dan bagaimana Filsafat Hukum di Indonesia. Jakarta: Gramedia Pustaka Utama.

Erwin Muhamad. 2012. Filsafat Hukum Refleksi Kritis terhadap hukum. Jakarta: Rajawali Pers.

Efendi Erdianto. 2010. Hukum Pidana Indonesia Suatu Pengantar. Pekan Baru. RefikaAditama.

Hamzah Andi. 2015. Hukum Pidana. Jakarta: Sofmedia.

Hiariej Eddy O.S. 2016. Prinsip-Prinsip Hukum Pidana. Yogyakarta: Cahaya Atma Pustaka.

Lamintang. P.A.F. 1997. Dasar-Dasar Hukum Pidana Indonesia. Bandung: PT Citra Aditya Bakti.

L. Tanya. Bernard dkk. 2006. Teori Hukum Strategi tertib Manusia Lintas Ruang dan Generasi. Surabaya: CV Kita.

Moeljatno. 1993. Asas-Asas Hukum Pidana. Jakarta: Rineka Cipta.

Mulyadi Lilik. 2007. Kapita Selekta Hukum Pidana Kriminologi \& Victimologi. Jakarta:

Djamban.

Prasetyo Teguh. 2016. Hukum Pidana, Jakarta: Raja Grafindo Persada.

Rasjidi Lili Rasjidi dan ira Thania rasjidi. 2007. Dasar-Dasar Filsafat dan Teori Hukum. Bandung: Citra Aditya Bakti.

2007. Pengantar Filsafat hukum. Bandung: Mandar Maju.

Salim. 2010. Perkembangan Teori dalam Ilmu Hukum, Jakarta: Rajawali Pers.

Santoso Agus M. 2012. Hukum, Moral E Keadilan Sebuah Kajian Filsafat Hukum.

Samarinda: Kencana Prenada Media Group.

Schaffmeister D., N. Keijzer, Sutorius. 2007. Hukum Pidana. Citra Aditya.

Tahir Heri. 2010. Proses Hukum Yang Adil Dalam Sistem Peradilan Pidana Di Indonesia. Yogyakarta: Laksbang Pressindo Yogyakarta. 